\title{
KLUGE'S LAW AND THE RISE OF PROTO-GERMANIC GEMINATES
}

\author{
by Frederik Kortlandt - Leiden
}

According to F. Kluge (1884: 174), "trat nach vollzug des zweiten lautverschiebungsaktes, d.h. nach der wirkung des Verner'schen gesetzes, die angleichung der betonten $n$-suffixe an die vorausgehenden tönenden laute ein. Nachdem sich so das gebiet der tönenden verschlusslaute erweitert hat, tritt der letzte verschiebungsakt ein, wodurch alle medien, einfache wie geminierte zu [tenues] werden." Though Kluge was not the first to propose the assimilation of suffixal $*_{n}$ to a preceding consonant in order to explain the rise of Proto-Germanic ${ }^{*} k k,{ }^{*} t t,{ }^{*} p p$, his presentation is rightly acknowledged as the canonical view in the later discussion of the problem. It therefore seems appropriate to call his rule "Kluge's law" (thus already Kauffmann 1887).

The rise of the voiceless geminates belongs to the most debated issues in Germanic linguistics. It has now received a comprehensive treatment in R. Lühr's Habilitationsschrift (1988), an impressive piece of work in the best German tradition (with 44 pages of bibliography and 2493 footnotes). ${ }^{1}$ After a detailed discussion of earlier treatments in terms of "expressive gemination" and "expressive nasalization" in the first two chapters of her book, the author concludes (188): "Es steht nichts im Wege, die Gemination oder den Konsonantenwechsel in den meisten der sogenannten 'Gefühlswörter' auf die gleiche Weise zu deuten wie im Falle von Wörtern neutralen Gefühlswertes." I agree whole-heartedly. ${ }^{2}$ In the central chapter of her book (189-215), Lühr presents her own theory, which basically conforms to Kluge's. She lists the following crucial arguments (191):

"1) Die Bedeutung der meisten Nomina mit Doppeltenuis oder Konsonantenwechsel läßt keine expressive, lautnachahmende oder Intensität beziehungsweise Iteration ausdrückende Lautgebung vermuten.

2) Die Doppelobstruenten treten vor allem in $n$-Stämmen auf, was in der Flexion dieser Stämme begründet ist.

3) $n$-Stämme mit $* l l<* l-n,{ }^{*} n n<* n-n$ verhalten sich morphologisch wie die $n$ Stămme mit Doppeltenuis.

1 I have noticed very few printing errors, mainly subscript dots missing in Indic forms $(199,200,312)$.

2 It follows that Fagan's theory (1989) must be rejected. 
4) Der Umstand, daß ein und dasselbe Wort Doppeltenuis aufweist und als $u$-Stamm flektiert, ist bei der Annahme einer nicht lautgesetzlichen Entstehung der Doppeltenues nicht erklärbar."

These arguments decide the issue. In the last two chapters, Lühr adduces lists of nouns and verbs and analyzes the material. She derives the intensive and iterative verbs with voiceless geminates from factitives on the basis of deverbal adjectives in $*_{-n a-}<*_{-n}$-, e.g. G. bücken 'stoóp', Skt. bhugná- 'bent', not from nasal presents. This is all very convincing.

Comparing Lühr's final text with her preliminary statement (1980), I find myself in agreement with her earlier rather than later analysis of the phonetic development involved. First of all, Kluge limited the assimilation rule to stressed nasal suffixes in view of such instances as Go. $a \not \bar{n} n$ 'year', auhns 'oven'. ${ }^{3}$ According to Lühr's more recent view (1988: 192), "erscheint es ratsam, den Akzent bei der Beschreibung der $n$-Gemination außer Betracht zu lassen, auch wenn sich mit Hilfe des Akzentes eine Reihe von Gegenbeispielen leichter erklären ließe." I certainly disagree. Secondly, Lühr reformulates Kluge's assimilation rule as gemination before $*_{n}$ and subsequent loss of the nasal. There is no material evidence for this view, which is based on an aprioristic theory of syllable structure. ${ }^{4} \mathrm{I}$ think that Kluge's formulation quoted above is superior to any modification which has been proposed since.

The relative chronology of Kluge's law poses a problem which has not been solved yet. On the one hand, the rise of the new geminates was posterior to Verner's law because it affected the voiced reflexes of the PIE. voiceless plosives in the same way as the original aspirates. ${ }^{5}$ On the other hand, the devoicing of the geminates suggests that it was anterior to Grimm's law, or at least to the "Medienverschiebung", as Kluge pointed out already. The logical conclusion is that Verner's law preceded Grimm's law, a chronology for which there is other evidence as well (cf. Kortlandt 1988: 5f.). Those who refuse to accept this conclusion can choose between two alternatives. Either they may assume that the voiced fricatives which resulted from Verner's law assimilated a following $*_{n}$ and became plosives (Kluge 1884: 175) or became plosives before $*_{n}$ which was then assimilated (Lühr 1980:

${ }^{3} \mathrm{Cf}$. already Sievers 1878: $149 \mathrm{fn}$., which Lühr does not meition in her book, and Osthoff 1882: $300 \mathrm{fn}$. The formulation that "nicht sicher ist, ob ein im Frühurgermanischen auf ein *-n-folgender Akzent die $n$-Gemination verhindert hat" (Lühr 1988: 331) is of course a slip of the pen.

4 On the detrimental influence of preconceived theoretical ideas on the investigation of the material see my discussion (1989) of Vennemann's application of this theory to Armenian data.

5 Thus already Paul 1880: 133 fn., which Lühr does not mention. 
259) before devoicing. Or they may assume that "zwischen der urgermanischen und der hochdeutschen lautverschiebung ausser der durch Verner aufgeklärten noch eine weitere verschiebung liegt, durch welche die lange verschlusslenis zur verschlussfortis verschoben wird" (Paul 1880: 133 fn.), "wobei die verdoppelten stimmhaften Reibelaute in der Gemination zunächst zu Verschlußlauten und dann wie im Oberdeutschen zu stimmlosen Verschlußlauten wurden" (Lühr 1988: 196), which means that it was "eine von der germanischen Lautverschiebung unabhängige spätere Erscheinung". Both solutions are unsatisfactory.

The problem can be resolved if we start from the reconstruction of the Proto-Germanic system of obstruents which I have presented earlier (1988). In my view, the PIE. aspirates lost their aspiration in dialectal Indo-European times already. They remained distinct from the "mediae" (unaspirated lenes) because the latter were preglottalized, as is clear from their reflexes in Balto-Slavic. After Verner's law had "das gebiet der tönenden verschlusslaute erweitert" (as Kluge put it), the remaining voiceless plosives were lenited to fricatives and voicedness was lost as a distinctive feature. This is Grimm's law. The resulting system of obstruents is preserved largely unchanged in modern Icelandic, except for the development of preglottalization into preaspiration, e.g. in epli 'apple', mikla 'increase', verk 'work'. We can now date Kluge's law between Verner's law and Grimm's law: this enables us to explain the attested reflexes from well-known developments without any additional assumptions.

The range of Kluge's law must not be underestimated. Lühr writes (1988: 250): "Nun erscheinen auch bei dem Wort Schiff Lautungen, die auf ein *pp weisen; diese sind in den etymologischen Wörterbüchern im allgemeinen nicht erwähnt", and she cites a number of forms on the basis of which "ist für das Althochdeutsche neben *skipa- ein *skippa-n. vorauszusetzen. [...] Demgegenüber weisen alle übrigen germanischen Sprachen allein auf eine Vorform mit einem urgerm. * $p$." The geminate is actually corroborated by Swedish skepp 'ship', which relates to ON skip as Sw. droppe 'drop', vecka 'week' relate to ON dropi, vika and can safely be taken to be the reflex of *skibna-<*skipnó-, cf. Lith. skiEpas 'graft'. It would be interesting to reconsider the whole problem of East Norse gemination against this background. Similarly, the root-final consonant of the word for 'deep' was probably taken from *dubna- <*dhubhnó-, Russ. dno 'bottom', cf. Lith. dubùs 'deep, hollow', with a short vowel pointing to *bh, not ${ }^{*} b$, also MHG topf 'pot' < 'vas profundum' (Luihr 1988: 232f. and 349f.). ${ }^{6}$ One can only hope that Kluge's law will now be recognized as

${ }^{6}$ Unfortunately, the usefulness of Liihr's book is reduced by the limited character of the index. Thus, the page numbers given here can only be found through the words 
an integral part of our knowledge in the standard treatments of Germanic historical linguistics.

\section{References}

Fagan S.M.B. 1989. Geminates in intensive and iterative Germanic class II weak verbs, in: $P B B$ 111, 35-58.

Kaufmann, F. 1887. Zur geschichte des germanischen consonantismus, in: $P B B$ 12, 504-547.

Kluge, F. 1884. Die germanische consonantendehnung, in: $P B B$ 9, 149-186.

Kortlandt, F. 1988. Proto-Germanic obstruents, in: $A B a ̈ G ~ 27,3-10$.

-"- 1989. The making of a puzzle, in: Annual of Armenian Linguistics 10, 43-52.

Lühr, R. 1980. Zu einem urgermanischen Lautgesetz, in: Lautgeschichte und Etymologie, 248-259. Wiesbaden: Reichert.

-"-. 1988. Expressivität und Lautgesetz im Germanischen. Heidelberg: Winter.

Osthoff, H. 1882. Ueber aoristpraesens und imperfectpraesens, in: $P B B$ 8, 287-311.

Paul, H. 1880. Beitraege zur geschichte der lautentwickelung und formenassociation, in: $P B B$ 7, 105-170.

Sievers, E. 1878. Zur accent- und lautlehre der germanischen sprachen, in: $P B B$ 5, 63-163.

Topf and tupfen, respectively, not through tief, OE doppettan, or the Celtic, Baltic, or Slavic cognates cited in the text. 